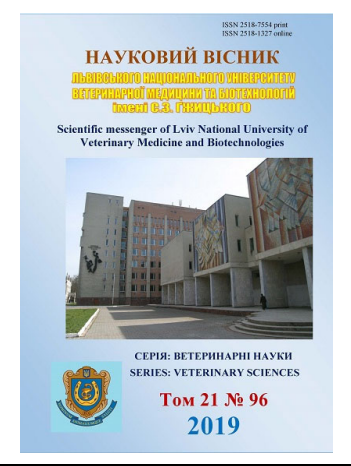

\author{
Науковий вісник Дьвівського національного університету \\ ветеринарної медицини та біотехнологій імені С.3. Гжицького. \\ Серія: Ветеринарні науки
}
Scientific Messenger of Lviv National University of Veterinary Medicine and Biotechnologies.
Series: Veterinary sciences

UDC 619:616:981:25

\title{
Characterization of the biological properties of bacteriophages Staphylococcus aureus variant bovis
}

Yu.V. Horiuk

State Agrarian and Engineering University in Podilya, Kamianets-Podilskyi, Khmelnytskyi region, Ukraine

Article info

Received 02.10.2019

Received in revised form 03.11 .2019

Accepted 04.11.2019

State Agrarian and Engineering University in Podilya,

Schevchenko Str., 13, Kamianets-

Podilskyi, Khmelnytskyi region,

32300, Ukraine.

Tel.: +38-097-661-79-64

E-mail: goruky@ukr.net
Horiuk, Yu.V. (2019). Characterization of the biological properties of bacteriophages Staphylococcus aureus variant bovis. Scientific Messenger of Lviv National University of Veterinary Medicine and Biotechnologies. Series: Veterinary sciences, 21(96), 47-52. doi: $10.32718 /$ nvlvet 9608

Cattle mastitis is the main cause of economic losses in milk production worldwide, and Staphylococcus aureus is the pathogen that causes it most. Bacteriophages may be an alternative treatment for this disease. In this study, we studied the effect of temperature and $\mathrm{pH}$ on the lytic activity of bacteriophages isolated from cows with signs of mastitis. The isolation and production of pure phage lines were performed on an indicator culture of Staphylococcus aureus var. bovis $1491 f$ conventional methods. The following phages were isolated and labeled: Phage SAvB07, Phage SAvB08, Phage SAvB12, Phage SAvB14. To determine the effect of temperature and $\mathrm{pH}$, aliquots after the action of these factors were sown by the double agar method at regular intervals. The study found that phage lytic activity was temperature dependent. Thus, under the influence of temperature $45^{\circ} \mathrm{C}$ after 30 minutes of action, it decreased by 3.0-3.4 times for bacteriophages Phage SAvB07, Phage SAvB08, Phage SAvB12 and after one hour was 2.4-12.6\%. Phage SAvB14 strain was more resistant to temperature. Its activity decreased by only $67.6 \%$ during the analyzed period. With higher temperatures $\left(55-65{ }^{\circ} \mathrm{C}\right)$, the intensity of phage infection decreased significantly, but remained stable. The most resistant to the effects of temperature was Phage SAvB14 - its activity was on average higher by 15.6-33.9\% compared with other phages taken in the experiment. The results of our studies on the effect of $\mathrm{pH}$ on the reproduction of phages showed that the maximum number of phage virions was observed at $p H 6$ 7. However, the most resistant to acidity was the phage strain Phage SAvB14, compared with other strains taken in the experiment. Therefore, the bacteriophage Phage SAvB14 exhibited the greatest stability and has considerable potential for in vivo use in the treatment of mastitis of cows caused by Staphylococcus aureus.

Key words: mastitis, bacteriophages, Staphylococcus aureus, lytic activity, temperature, $p H$.

\section{Характеристика біологічних властивостей бактеріофагів Staphylococcus aureus variant bovis}

\author{
Ю.В. Горюк
}

Подільський державний аграрно-технічний університет, м. Кам'янець-Подільський, Хмельницька обл., Украӥна

\footnotetext{
Мастит великої рогатої худоби є основною причиною економічних втрат у виробництві молока в усьому світі, а золотистий стафілокок - збудник, який найчастіше його викликає. Бактеріофаги можуть бути альтернативним методом лікування цьвого захворювання. В даному дослідженні ми вивчали вплив температури і рН середовища на літичну активність бактеріофагів, виділених від корів з ознаками маститу. Виділення та отримання чистих ліній фагів проводили на індикаторній культурі Staphylococcus aureus var. bovis $1491 f$ загальноприйнятими методами. Виділено і позначено наступні фаги: Phage SAvB07, Рhage SAvB08, Phage SAvB12, Phage SAvB14. Для визначення впливу температури та рН аліквоти після діï зазначених чинників висівали методом подвійного агару через певні проміжки часу. За результатами дослідження встановлено, ше фагова літична активність залежала від температури. Так, за впливу температури $45{ }^{\circ}$ С через 30 хвилин дї вона знизилася в 3,0-3,4 разу для бактеріофагів
} 
Phage SAvB07, Phage SAvB08, Phage SAvB12, і через одну годину була в межах 2,4-12,6\%. Стійкішим до впливу температури був штам Phage SAvB14. Його активність знизилася лише на 67,6\% протягом аналізованого періоду. За впливу вищих температур $\left(55-65{ }^{\circ} \mathrm{C}\right)$ інтенсивність фагової інфекиії значно знижувалася, проте залишалася стабільною. Найбільи стійким до впливу температури виявився Phage SAvB14 - його активність була в середньому вища на 15,6-33,9\% порівняно з іншими фагами, взятими в дослід. Результати наших досліджень щодо впливу рН на репродукиію фагів показали, щяо максимальна кількість фагових віріонів спостерігалася при рН 6-7. Проте найбільш стійким до зміни кислотності був штам фагу Phage SAvB14, порівняно з іншими штамами, взятими в дослід. Отже, бактеріофаг Phage SAvB14 проявляв найбільшу стабільність і має значний потенціал для застосування іп vivo при лікуванні маститів корів, спричинених золотистим стафілококом.

Ключові слова: мастит, бактеріофаги, золотистий стафілокок, літична активність, температура, рН.

\section{ВстуII}

Багато різних видів бактерій мають здатність викликати інфекцію молочної залози великої рогатої худоби, і реакція організму на ці інфекції - це те, що ми називаємо маститом. Золотистий стафілокок поширений і небезпечний збудник, що викликає різні інфекційні захворювання, включаючи мастити у корів (Kukhtyn et al., 2016; Horiuk et al., 2018). Лікування цього захворювання стає все складнішим через поширення полірезистентних штамів стафілококів (Horiuk et al., 2019). Тому існує нагальна потреба в розробці нових терапевтичних засобів, спрямованих проти цього патогенна (O'Flaherty et al., 2005a; Jensen et al., 2015; Moodley et al., 2019).

Існує багато альтернативних методів лікування маститів у корів, такі як використання вакцин
(Gogoi-Tiwari et al., 2015), рослинних екстрактів (Karreman, 2007), фаготерапія (Lin et al., 2017; Horiuk, 2018). Враховуючи різноманіття інформації, фаготерапія є однією з найбільш надійних засобів боротьби 3 маститом великої рогатої худоби.

Вчені виділяли та досліджували різні фаги 3 літичною дією щодо S. aureus (Dias et al., 2013; Jensen et al., 2015; Moodley et al., 2019). Антибактеріальний ефект препаратів бактеріофагів обумовлений впровадженням генома фага в бактеріальну клітину з подальшим його розмноженням і лізисом інфікованої клітини (Hanlon, 2007). Фаги, що вийшли в зовнішнє середовище в результаті лізису бактерії, повторно інфікують і лізують інші бактеріальні клітини, діючи до повного знищення патогенних бактерій у вогнищі запалення (рис. 1) (Mahony et al., 2011).

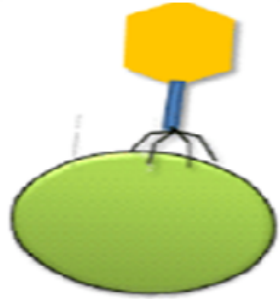

Алсорбція фагу
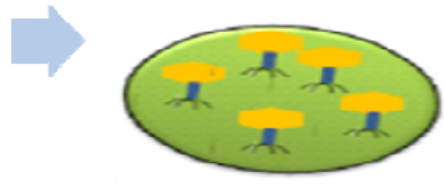

Розмноження фагів в середпні бактеріі

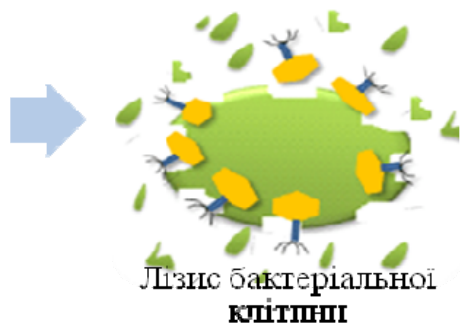

кगіTIIII

Рис. 1. Життєвий цикл літичного бактеріофага

Проте на даний час дослідники звертають недостатньо уваги на можливість використання специфічних бактеріофагів, виділених 3 вогнища інфекції, проти конкретного захворювання. Особливо це стосується такого захворювання, як субклінічний мастит корів, що завдає значних економічних збитків через розвиток антибіотикорезистентності у збудників та необхідність бракування молока (Hanlon, 2007; Kukhtyn et al., 2016; Kovalenko et al., 2018).

Хоча кожне дослідження мало вагомі результати, варто зазначити, що існують певні обмеження при використані їx in vivo. Фагова інактивація може бути викликана молочними білками та жирами (O'Flaherty et al., 2005b), агрегацією клітин $S$. aureus всередині залози (O'Flaherty et al., 2005a) та імунними факторами самої корови (O'Flaherty et al., 2005b). Тому існує необхідність вивчення впливу різних факторів на активність фагів для правильного застосування фагових препаратів внутрішньовименно та їхню здатність діяти в інтрамамальному середовищі.
Основною метою цього дослідження є вивчення чутливості фагів до температури та $\mathrm{pH}$ середовища in vitro для моделювання ситуації при застосуванні їx in vivo.

\section{Матеріал і методи досліджень}

Для виділення та нарощення титру бактеріофагів використовували штам золотистого стафілококу Staphylococcus aureus var. bovis 1491f, який виділений зі зразка секрету молочної залози ВРХ, хворої субклінічною формою маститу, та первісно депонований в Депозитарії Державного науково-контрольного інституту біотехнології і штамів мікроорганізмів під номером 736 (Свідоцтво на штам від 05.03.2019).

Виділення фагів проводили зі зразків молока 3 умістом соматичних клітин понад 400 тис/ $\mathrm{cm}^{3}$. Первинне виділення та отримання чистих ліній бактеріофагів проводили за методикою, розробленою Oliveira et al. (Merabishvili et al., 2009). Досліджуваний матеріал засівали в МПБ. Одночасно в живильне середови- 
ще вносили 0,2-0,5 мл, або повну бактеріальну петлю добової культури $S$. aureus var. bovis. Флакони з посівами ставили в термостат при $37^{\circ} \mathrm{C}$, на 18-20 годин. Після інкубації вміст флаконів фільтрували через фільтри для звільнення від механічних домішок. Після цього вміст розливали в стерильні пробірки, центрифугували при 3000 об./хв протягом 30 хвилин. Надосад очищували від сторонньої мікрофлори, використовуючи двоступеневу фільтрацію: мембранні фільтри 3 діаметром пор 0,45 мкм (Sartorius, Німечина); Отриманий фаголізат досліджували на наявність фагів. Літичну активність бактеріофагів, а також морфологію негативних колоній вивчали за методом Граціа. Для цього готували $1,5 \%$ МПА і розливали в стандартні чашки Петрі по 25,0-30,0 мл. Агар підсушували в термостаті протягом 30 хвилин. Окремо готували 0,7\% МПА (напіврідкий), розливали його в пробірки і стерилізували звичайним методом. В пробірки з $0,7 \%$ МПА розплавленим і охолодженим до $45^{\circ} \mathrm{C}$ додавали по 1 мл фаголізату і 0,2 мл добової бульйонної індикаторної культури. Вміст пробірок перемішували і наливали подвійним шаром в чашки Петрі 3 $1,5 \%$ МПА. Посіви інкубували за температури $(37 \pm 1){ }^{\circ} \mathrm{C}$ упродовж 18-24 год. Таким чином, виділено і позначено такі фаги: Phage SAvB07, Phage SAvB08, Phage SAvB12, Phage SAvB14.

Для визначення впливу високих температур на активність виділених фагів готували розведення кожного штаму з розрахунку $10^{5}$ БУО/мл. Кожне розведення поміщали у водяну баню за різних температур: 35 (контроль), 45, 55, $65{ }^{\circ} \mathrm{C}$. Через кожні 10 хвилин проводили відбір певної аліквоти досліджуваних зразків, додавали тест-культуру і висівали методом двошарового агару. Чашки інкубували за температури $37^{\circ} \mathrm{C}$ протягом 18-24 год. Дослідження проводили в трьох повторах.

Для визначення впливу $\mathrm{pH}$ середовища на активність фагів поживний бульйон було відкалібровано (використовуючи $1 \mathrm{M} \mathrm{HCl}$ ) відповідно до таких діапа-

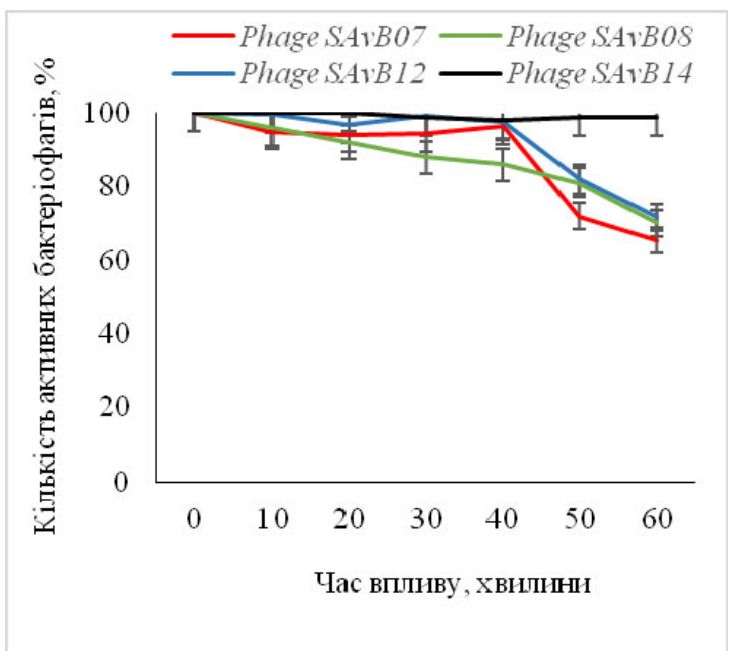

A зонів pH: 2, 4, 6, 8, 10, 12 і 14. Кожне розведення бактеріофагів додавали до відкаліброваного бульйону 3 розрахунку, щоб в кінцевому результатів вміст фагів був $10^{5}$ БУО/мл. Зразки витримували при кімнатній температурі протягом 1 години. Потім відбирали аліквоти досліджуваних зразків, додавали чутливу добову культуру і висівали методом двошарового агару. Чашки інкубували за температури $37{ }^{\circ} \mathrm{C}$ протягом $18-$ 24 год. Дослідження проводили в трьох повторах.

Статистичну обробку результатів здійснювали методами варіаційної статистики з використанням програми Statistica 9.0 (StatSoft Inc., USA). Застосовували непараметричні методи досліджень (критерії Уїлкоксона, Манна-Уїтні). Визначали середнє арифметичне (x), стандартну похибку середньої величини (SE).

\section{Результати досліджень}

За результатами досліджень встановлено, що підвищення температури в поєднанні зі збільшенням часу впливу цієї температури знижує літичну активність виділених фагів (рис. 2). Так, кількість активних фагів за впливу температури $45^{\circ} \mathrm{C}$ протягом перших 10 хвилин знизилася на 40,7-27,6\%. Лише кількість активного фагу Phage $S A v B 14$ була майже незмінною. Температура 55-65 ${ }^{\circ} \mathrm{C}$ згубно діяла на всі досліджувані штами бактеріофагів. За перші 10 хвилин впливу кількість життєздатних фагів знизилася на 29,9-61,7 та 60,3-90,1\% відповідно. В подальшому фагова репродуктивна активність відносно стабілізувалася в усіх діапазонах температур, але залишалася низькою. Крім того, були відзначенні відміності між кожним фагом. Найбільш стійким до впливу температури виявився Phage $S A v B 14$ - його активність була в середньому вища на 15,6-33,9\% порівняно з іншими фагами, взятими в дослід.

Усі досліджувані фаги (Phage SAvB07, Phage $S A v B 08$, Phage $S A v B 12$, Phage $S A v B 14)$ виявилися чутливими до зміни рН середовища (рис. 3).

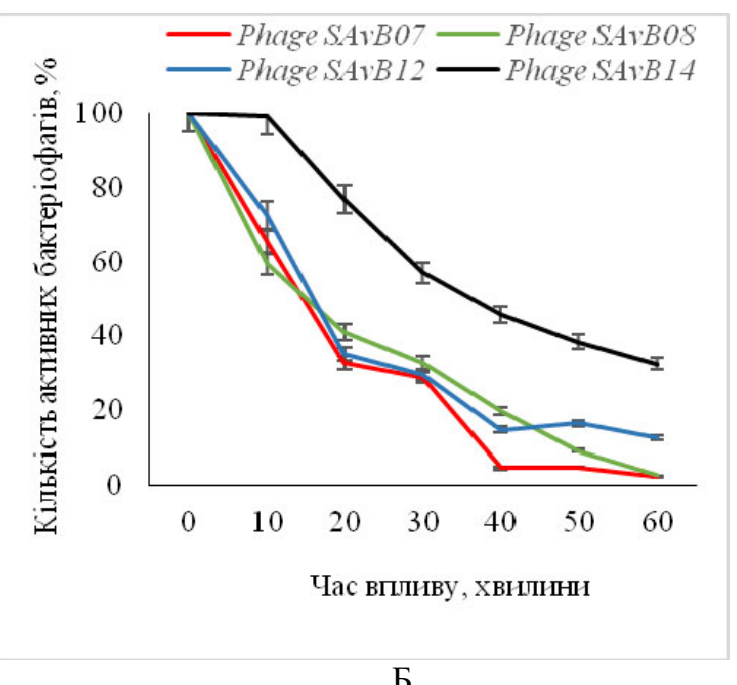

Б 


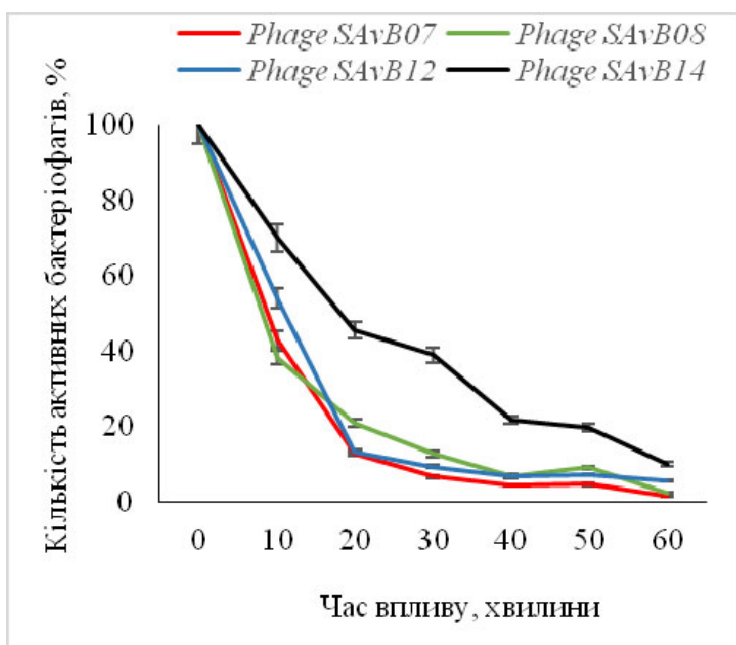

B

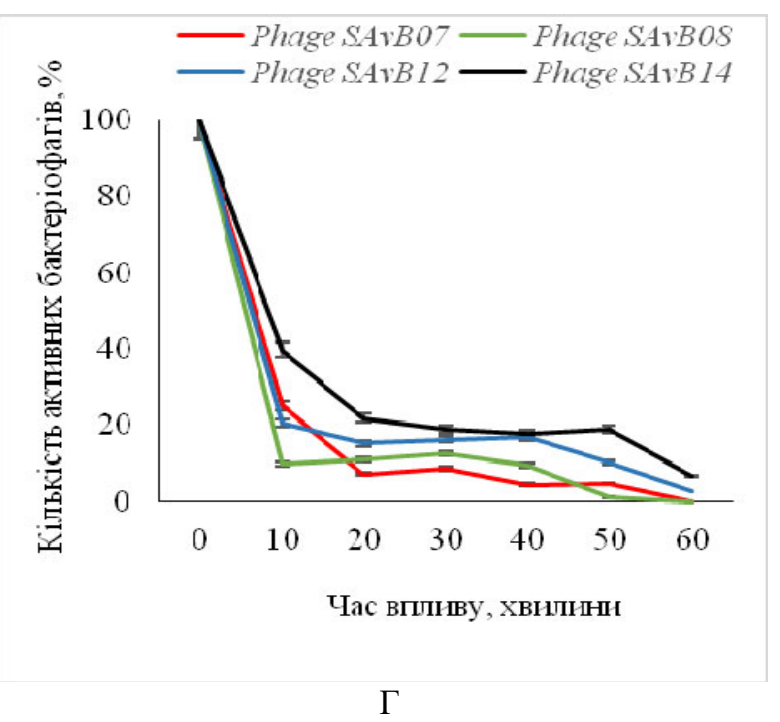

$\Gamma$

Рис. 2. Вплив температури на літичну активність бактеріофагів: А - температура $35 \pm 2{ }^{\circ} \mathrm{C}$ (контроль); Б $-45 \pm 2{ }^{\circ} \mathrm{C} ; \mathrm{B}-55 \pm 2{ }^{\circ} \mathrm{C} ; \Gamma-65 \pm 2{ }^{\circ} \mathrm{C}$. Дані подано як середнє значення \pm стандартне відхилення

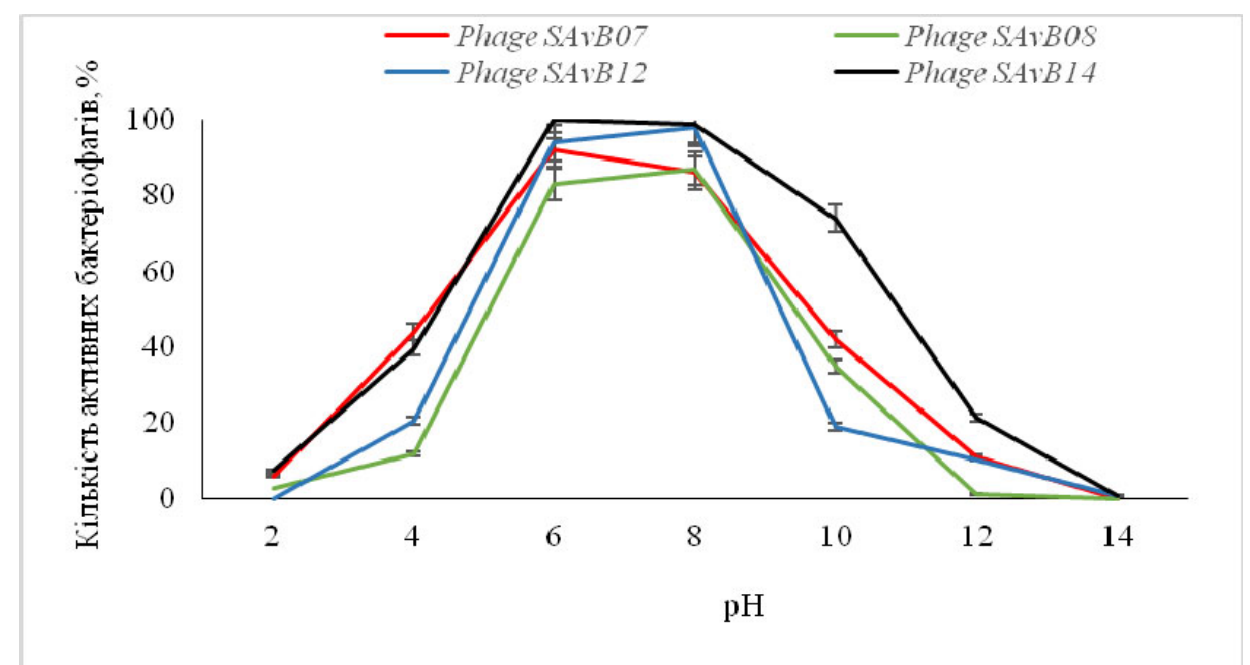

Рис. 3. Вплив рН на літичну активність бактеріофагів. Дані подано як середнє значення \pm стандартне відхилення

Згубно на активність фагів діяли як низькі, так і високі значення $\mathrm{pH}$. Найбільшу стабільність вони проявили при значенні $\mathrm{pH}$ в межах 6-7, тобто близькому до нейтрального. Поза цими значеннями активність значно знижувалася.

Загалом отримані результати досліджень показали, що виділені бактеріофаги в тій чи іншій мірі стійкі до зміни температури та $\mathrm{pH}$ середовища. Проте найбільш широкий діапазон термічної та $\mathrm{pH}-$ стійкості проявив фаг Phage SAvB14.

\section{Обговорення}

Антибіотикорезистентність S. aureus та складність лікування викликаних ним захворювань свідчать про необхідність альтернативної терапії маститу корів. Фаги пропонують цю альтернативу (Merabishvili et al., 2009; Moodley et al., 2019). Однак існує декілька проблем, пов'язаних із застосуванням фагів в інтрамамальному середовищі через вплив на них різних еколо- гічних та хімічних факторів (Dias et al., 2013; Moodley et al., 2019). Основною метою цього дослідження було оцінити вплив температури та $\mathrm{pH}$ середовища на активність бактеріофагів in vitro.

Вплив температури на фагову активність має велике значення (Jensen et al., 2015; Rehman et al., 2016; Kukhtyn et al., 2017; Klopatek et al., 2018). При тестуванні впливу ступеня прогрівання на фаги оцінюють їхню здатність якнайдовше зберігати свої властивості при найвищих температурах (Jensen et al., 2015; Rehman et al., 2016; Kukhtyn et al., 2017). Це пояснюється тим, що в природних умовах застосування фагів вимагає толерантності до коливання температурних режимів. Зміна температури може виникнути через погодні умови при зберіганні чи транспортуванні фагових препаратів, фізіологічні зміни в організмі тварин. Усі досліджені нами фаги показали зниженя літичної активності вже через 10 хв за температури $45^{\circ} \mathrm{C}$. 
При промисловому виготовленні медикаментів деякі процеси можуть вимагати високого температурного режиму. Це важливо, особливо з точки зору комерційного виробництва фагових препаратів. Фаги насамперед складаються 3 білка (Wills et al., 2005; Svircev et al., 2018) і будь-який тривалий вплив високої температури може спричинити денатурацію фагових білків, що відповідають за інфікування бактерійгосподарів. Наші результати співвідносяться 3 попередніми дослідженнями, де показано, що літична здатність фага знижується при тривалому впливі високих температур (Hanlon, 2007; Mahony et al., 2011; Saglam et al., 2017).

pH середовища, в якому розмножується фаг, також $\epsilon$ важливим чинником (O’Flaherty et al., 2005a; Saglam et al., 2017). Оптимальні значення водневого показника для росту і розмноження бактеріофагів в умовах in vitro мають бути максимально наближеними до природного середовища, з якого виділений даний фаг. $\mathrm{pH}$ молока перебуває в межах 6,6-6,7. Результати наших досліджень показали, що максимальна реплікація фагів відбулася при $\mathrm{pH}$ 6-7. Схожі результати були отримані іншими вченими. Вивчалася стабільність щодо рН в буферах при діапазоні рH 2-12. Фаг SLPW, який активний проти Methicillin-Resistant Staphylococcus aureus, показав відносно високий piвень виживання (понад 80\%) при рН від 6 до 10. Поза цими значеннями активність різко знижувалася (Wang et al., 2016).

\section{Висновки}

Проведені дослідження визначають оптимальні умови для зберігання фагової активності бактеріофагів Phage $S A v B 07$, Phage SAvB08, Phage SAvB12, Phage $S A v B 14$. Відхилення від стандартних умов зберігання фагів призвели до різкого зниження фагової активності. Проте фаг Phage $S A v B 14$ стійкіший до впливів високих температур і коливання $\mathrm{pH}$ порівняно 3 iншими дослідженими фагами, а отже $є$ кращим для створення препарату проти стафілококового маститу корів.

\section{References}

Dias, R.S., Eller, M.R., Duarte, V.S., Pereira, A.L., Silva, C.C., Mantovani, H.C., Oliveira, L.L., Silva, E. de A.M, \& Paula, S.O. (2013). Use of phages against antibiotic-resistant Staphylococcus aureus isolated from bovine. Journal of Animal Science, 91(8), 3930-3939. doi: $10.2527 /$ jas.2012-5884.

Gogoi-Tiwari, J., Williams, V., Waryah, C.B., Eto, K.Y., Tau, M., Costantino, P., \& Mukkur, T. (2015). Comparative studies of the immunogenicity and protective potential of biofilm vs planktonic Staphylococcus aureus vaccine against bovine mastitis using non-invasive mouse mastitis as a model system. Biofouling, 31(7), 543-554. doi: 10.1080/08927014.2015.1074681.

Hanlon, G.W. (2007). Bacteriophages: an appraisal of their role in the treatment of bacterial infections. In- ternational Journal of Antimicrobial Agents, 30(2), 118-128. doi: 10.1016/j.ijantimicag.2007.04.006.

Horiuk, Y.V. (2018). Fagotherapy of cows mastitis as an alternative to antibiotics in the system of obtaining environmentally safe milk. Scientific Messenger of LNU of Veterinary Medicine and Biotechnologies. Se-ries: Veterinary Sciences, 20(88), 42-47. doi: $10.32718 /$ nvlvet8807.

Horiuk, Yu., Kukhtyn, M., Kovalenko, V., Kornienko, L., Horiuk, V., \& Liniichuk, N. (2019). Biofilm formation in bovine mastitis pathogens and the effect on them of antimicrobial drugs. Independent Journal of Management \& Production, 10(7), 897-910. doi: 10.14807/ijmp.v10i7.1012.

Horiuk, Yu.V., Kukhtyn, M.D., Perkiy, Yu.B., \& Horiuk, V.V. (2018). Distribution of main pathogens of mastitis in cows on dairy farms in the western region of Ukraine. Scientific Messenger of Lviv National University of Veterinary Medicine and Biotechnologies, 20(83), 115-119. doi: 10.15421/nvlvet8322.

Jensen, K.C., Hair, B.B., Wienclaw, T.M., Murdock, M.H., Hatch, J.B., Trent, A.T., \& Berges, B.K. (2015). Isolation and host range of bacteriophage with lytic activity against methicillin-resistant Staphylococcus aureus and potential use as a fomite decontaminant. PLoS One, 10(7), e0131714. doi: 10.1371/journal.pone.0131714.

Karreman, H.J. (2007). Phytotherapy for dairy cows. Veterinary Herbal Medicine. SG Wynn and BJ Fougere, ed. Mosby, St. Louis, MO.

Klopatek, S., Callaway, T.R., Wickersham, T., Sheridan, T.G., \& Nisbet, D.J. (2018). Bacteriophage Utilization in Animal Hygiene. Bacteriophages: Biology, Technology, Therapy, 1-28. doi: 10.1007/978-3-31940598-8_30-1.

Kovalenko, V.L., Kovalenko, P.L., Ponomarenko, G.V., Kukhtyn, M.D., Midyk, S.V., Horiuk, Y.V., \& Garkavenko, V.M. (2018). Changes in lipid composition of Escherichia coli and Staphylococcus areus cells under the influence of disinfectants Barez $\AA$, Biochlor ${ }^{\circledR}$ and Geocide $\AA$. Ukrainian Journal of Ecology, 8(1), 547-550. doi: 10.15421/2018_248.

Kukhtyn, M.D., Horyuk, Y.V., Horyuk, V.V., Yaroshenko, T.Y., Vichko, O.I., \& Pokotylo, O.S. (2017). Biotype characterization of Staphylococcus aureus isolated from milk and dairy products of private production in the western regions of Ukraine. Regulatory Mechanisms in Biosystems, 8(3), 384-388. doi: 10.15421/021759.

Kukhtyn, M.D., Kovalenko, V.L., Horyuk, Y.V., Horyuk, V.V., \& Stravskyy, Y.S. (2016). Bacterial biofilms formation of Cattle mastitis pathogens. Journal for Veterinary Medicine, Biotechnology and Biosafety, 2(4), 30-32. http://jvmbbs.kharkov.ua/archive/2016/ volume2/issue4/pJVMBBS_2016024_030-032.pdf.

Lin, D.M., Koskella, B., \& Lin, H.C. (2017). Phage therapy: an alternative to antibiotics in the age of multidrug resistance. World journal of gastrointestinal pharmacology and therapeutics, 8(3), 162. doi: 10.4292/wjgpt.v8.i3.162. 
Lopetuso, L., Giorgio, M., Saviano, A., Scaldaferri, F., Gasbarrini, A., \& Cammarota, G. (2019). Bacteriocins and Bacteriophages: Therapeutic Weapons for Gastrointestinal Diseases? International Journal of Molecular Sciences, 20(1), 183. doi: 10.3390/ijms20010183.

Mahony, J., McAuliffe, O., Ross, R.P., \& van Sinderen, D. (2011). Bacteriophages as biocontrol agents of food pathogens. Current Opinion in Biotechnology, 22(2), 157-163. doi: 10.1016/j.copbio.2010.10.008.

Merabishvili, M., Pirnay, J. P., Verbeken, G., Chanishvili, N., Tediashvili, M., Lashkhi, N., Glonti, T., Krylov, V., Mast, J., Van Parys, L., Lavigne, R., Volckaert, G., Mattheus, W., Verween, G., De Corte, P., Rose, T., Jennes, S., Zizi, M., De Vos, D., \& Vaneechoutte, M. (2009). Quality-controlled small-scale production of a well-defined bacteriophage cocktail for use in human clinical trials. PLoS One, 4(3), e4944. doi: 10.1371/journal.pone.0004944.

Moodley, A., Kot, W., Nalgard, S., Jakociune, D., Neve, H., Hansen, L. H., \& Vogensen, F.K. (2019). Isolation and characterization of bacteriophages active against methicillin-resistant Staphylococcus pseudintermedius. Research in Veterinary Science, 122, 81-85. doi: 10.1016/j.rvsc.2018.11.008.

O'Flaherty S, Ross RP, Flynn J, Meaney WJ, Fitzgerald GF, Coffey A (2005a). Isolation and characterisation of two anti-staphylococcal bacteriophages specific for pathogenic Staphylococcus aureus associated with bovine infections. Letters in Applied Microbiology, 41, 482-486. doi: 10.1111/j.1472-765X.2005.01781.x.

O'Flaherty, S., Coffey, A., Meaney, W. J., Fitzgerald, G. F., \& Ross, R.P. (2005b). Inhibition of bacteriophage
$\mathrm{K}$ proliferation on Staphylococcus aureus in raw bovine milk. Letters in Applied Microbiology, 41, 247279. doi: 10.1111/j.1472-765X.2005.01762.x.

Rehman, S., Khan, T., \& Raza, S. (2016). Isolation of bacteriophage against Staphylococcus aureus causing mastitis. International Journal of Advanced Multidisciplinary Research, 3(4), 1393-1395.

Saglam, A. G., Sahin, M., Celik, E., Çelebi, O., Akca, D., \& Otlu, S. (2017). The role of staphylococci in subclinical mastitis of cows and lytic phage isolation against to Staphylococcus aureus. Veterinary World, 10(12), 1481. doi: 10.14202/vetworld.2017.1481-1485.

Svircev, A., Roach, D., \& Castle, A. (2018). Framing the future with bacteriophages in agriculture. Viruses, 10(5), 218. doi: 10.3390/v10050218.

Topuzoglu, B, Bastan, A., \& Salar, S. (2015). The effect of long term antibiotic treatment on bacteriological cure and somatic cell count at subclinical mastitis due to Staphylococcus aureu s in lactating dairy cows. Veterinary Journal of Ankara University, 62, 289294.

Wang, Z., Zheng, P., Ji, W., Fu, Q., Wang, H., Yan, Y., \& Sun, J. (2016). SLPW: A virulent bacteriophage targeting methicillin-resistant Staphylococcus aureus in vitro and in vivo. Frontiers in microbiology, 7, 934. doi: 10.3389/fmicb.2016.00934.

Wills, Q. F., Kerrigan, C., \& Soothill, J. S. (2005). Experimental bacteriophage protection against Staphylococcus aureus abscesses in a rabbit model. Antimicrobial Agents and Chemotherapy, 49(3), 1220-1221. doi: 10.1128/AAC.49.3.1220-1221.2005. 